\title{
Review and Analysis on Foreign and Domestic Standards on Building External Envelope Overall Air Tightness
}

\author{
WangZhao ${ }^{1, a}$, LiZhen2,b, ShiJinglei3,c, LiDi4,d, WeiLinbin ${ }^{5, e}$ \\ 1Shandong Academy of Building Research, Jinan ,250031, China \\ 2Shandong Academy of Building Research, Jinan ,250031, China \\ 3Shandong Academy of Building Research, Jinan ,250031, China \\ 4Shandong Academy of Building Research, Jinan ,250031, China \\ 5Shandong Academy of Building Research, Jinan ,250031, China
}

aemail:sdjkt@163.com, ${ }^{\text {bemail:lizhenn4014@sina.com, }{ }^{c} e m a i l: s h i j i n g l e i 1987 @ 163 . c o m, ~ d e m a i l: 1865 ~}$

3164200@163.com, eemail:187278233@qq.com

\section{Keywords: Air leakage Air tightness Blower door testing}

\begin{abstract}
Air-conditioning system energy consumption accounts for a large proportion of building energy consumption.air-conditioning energy consumption caused by building envelope air leakage is very large, building envelope air leakage will also cause many direct or indirect harm, so enhancing air tightness detection of envelope shall be valued. By reviewing foreign and domestic standards on building external envelope overall air tightness, the differences and similarities between Related foreign and domestic standards are compared, and some suggestions are proposed on current situations and improvements of building external envelope air leakage in our country.
\end{abstract}

\section{Foreword}

At present, our country is preparing route diagrams for improving building energy efficiency. The time span is from 2016 to 2030, which covers future three five-year plans. The route diagrams include future development targets, technical routes and support conditions. The contents involve various aspects such as technical innovation systems, industrial support systems, spread and application systems and policy and regulation systems. Their guide ideas are to improve the lowest mandatory requirements of building energy efficiency standards continuously, to increase building energy efficiency working strength gradually, to improve building energy efficiency level completely, and to reach almost zero energy consumption gradually.

One of important technical methods of realizing almost zero energy consumption is to reduce building air-conditioning and heating energy consumption. Main technical measures include improving exterior wall and exterior window thermal insulation, reducing heat loss caused by air infiltration, introducing fixing quantity ventilation equipment, using efficient air interchanger with heat recovery, etc..

Reducing air infiltration needs enhance overall air tightness of building envelope. Foreign researches indicate in area with heating degree day of 2,500 $\left({ }^{\circ} \mathrm{C} \cdot \mathrm{d}\right)$, enhancing air tightness of building external envelope can decrease heat demand by $10 \mathrm{kWh} /\left(\mathrm{m}^{2} \cdot \mathrm{a}\right)$. In England, if under indoor and outdoor pressure difference of $50 \mathrm{~Pa}$, reducing air leakage of unit envelope area from $11.5 \mathrm{~m}^{3} /\left(\mathrm{m}^{2} \cdot \mathrm{h}\right)$ to $5 \mathrm{~m}^{3} /\left(\mathrm{m}^{2} \cdot \mathrm{h}\right)$ can reduce air-conditioning energy consumption by $15 \%{ }^{[1-2]}$.

In recent years, research on similar aspects has been implemented in China, especially by practice on Sino-German passive low energy consumption building demonstration project, deeper understanding is reached on building external envelope overall air tightness. By comparing with foreign countries, there aren't test methods and evaluation standards of perfect building external envelope overall air tightness in China. By referring to foreign experience, if our country wants to reach higher building energy efficiency target in the future, building external envelope 的 overall 
air tightness technical index that are suitable for national conditions of our country shall be established ${ }^{[3-4]}$.

Air tightness test on building external envelope isn't special requirement of passive house, many European countries now propose technical requirements on building external envelope overall air tightness, especially various countries such as England, French, Portugal and Denmark make mandatory requirements on building overall air tightness test. In America, "International Energy Conservation Code (ICECC)" (2012 Edition) also stipulates envelope overall air tightness technical index, and requires mandatory test. Washington is the first state that requires building above 6 stories to make overall air tightness test.

\section{Introduction on foreign and domestic standards}

\section{Europe standard EN $13829^{[5]}$}

At present, the standard implemented in Europe is EN 13829 "Thermal Performance of Buildings. Determination of Air Permeability of Buildings.Fan Pressurization Method”. The standard stipulates detailed requirements and descriptions on various contents such as building air tightness technical index, instrument and equipment, test procedure and test report.

\subsection{Technical index}

The standard defines several expressions of air tightness technical index, $\mathrm{N}_{50}$ (air change rate) is ventilation rate at indoor and outdoor pressure difference of $50 \mathrm{~Pa}, \mathrm{~h}^{-1} ; \mathrm{Q}_{50}$ (air permeability) is air leakage pf unit external envelope area in unit time at indoor and outdoor pressure difference of 50Pa, $\mathrm{m}^{3} /\left(\mathrm{m}^{2} \cdot \mathrm{h}\right) . \mathrm{W}_{50}$ (specific leakage rate) is air leakage of unit building area in unit time at indoor and outdoor pressure difference of $50 \mathrm{~Pa}, \mathrm{~m}^{3} /\left(\mathrm{m}^{2} \cdot \mathrm{h}\right)$.

1.2 Instrument and equipment

Blowing equipment: It can test positive pressure and negative pressure of building. The equipment can read air flow under fixing pressure difference.

Pressure difference measuring equipment: equipment accuracy is \pm 2 Pa within span range of 0-60 Pa.

Air flow measuring equipment: Reading error is $\pm 7 \%$.

Temperature test equipment: Equipment accuracy is $\pm 1 \mathrm{~K}$.

\subsection{Main test procedure}

Test conditions: Product from multiplying building indoor and outdoor temperature difference by building external envelope height shall be below $500 \mathrm{~m} \cdot \mathrm{K}$. outdoor wind speed shall be below $6 \mathrm{~m} / \mathrm{s}$ or wind force is below grade 3 .

Pressure difference measuring: It shall ensure influence of blowing equipment isn't born when building indoor and outdoor pressure difference is measured; External pressure sensor shall not be influenced by outdoor dynamic pressure. Recommending method is to place external pressure sensor into one T-type tee or box with outer hole; during winter measuring, external pressure sensor shall keep certain distance with building. Main test procedure is as following:

(1) Check overall sealing situation of building.

(2) Record indoor and outdoor temperature and wind speed before, after and during test.

(3) Turn off pressure difference measuring equipment, and zero the equipment. Before test starts, seal opening part of blower temporarily, record building indoor and outdoor pressure difference at this moment, and test duration isn't less than 30 seconds. The next test can be made only when average pressure difference isn't more than $5 \mathrm{~Pa}$ After envelope air tightness test is finished, repeat above test procedure again. If average pressure difference exceeds $5 \mathrm{~Pa}$, the test results aren't valid, test shall be made again.

(4) Setting of pressure difference

Air tightness test shall make multi-point test, and curvefit test results. Maximum pressure difference setting is minimum $50 \mathrm{~Pa}$ for small building, and pressure difference of $50 \mathrm{~Pa}$ shall be used as far as possible for large building (volume more than $4,000 \mathrm{~m}^{3}$ ). If pressure difference of 50 Pa can't be reached, several blowers in parallel can be used for testing so as to ensure pressure difference reaches at least $25 \mathrm{~Pa}$. 
Setting of the lowest pressure difference is at least $10 \mathrm{~Pa}$ or 5 times of pressure difference value in Step 3.

According to interval that isn't more than $10 \mathrm{~Pa}$, test points are set at the highest pressure difference value and the lowest pressure difference value, and all test points aren't less than 5 pieces.

(5) Main contents of test report

Test report shall show complete information of test object, for example, test position, size, area, volume and sealing situation of building; pressure difference before and after test, indoor and outdoor temperature, wind speed, atmospheric pressure, test process table, curvefitting formula, relevant coefficient $\mathrm{R}$ vale and various technical index under pressure difference of $50 \mathrm{~Pa}$.

\section{England standard TM23 ${ }^{[6]}$}

England building air tightness test standards are mainly stipulated by CIBSE (The Chartered Institution of Building Services Engineers). In England, CIBSE is technical authoritative organization in building engineering field. The organization stipulates relevant technical guidelines, standards and other guidance documents in England building engineering field.

CIBSE Technical Memoranda TM23: 2000 “Testing Buildings for Air Leakage” is building air tightness test standard prepared by CIBSE. The standard is prepared on the basis of EN 13829 standard. Main differences with EN 13829 are mainly shown in following aspects:

(1) EN 13829 requires during winter measuring, External pressure sensor shall keep certain distance with building. TM23 stipulates the distance shall be better about 10m.

(2) Test conditions: During test, indoor and outdoor temperature difference shall be below $10^{\circ} \mathrm{C}$, and wind speed shall be below $3 \mathrm{~m} / \mathrm{s}$.

(3) Equivalent leakage area: The standard adds equivalent leakage area index for the convenience of understanding and quantifying leakage degree. Equivalent leakage area is to be equivalent all leakage areas of building to area of one leakage point area, and calculation formula is as following:

$\mathrm{ELA}=\mathrm{Q}(\rho / 2 \Delta P)^{0.5}$

ELA:Equivalent leakage area, $\mathrm{m}^{2}$;

$\rho$ : Air density, $\mathrm{kg} / \mathrm{m}^{3}$;

$\Delta \mathrm{P}$ : Indoor and outdoor pressure difference, Pa. Reference pressure is normally 4-10 $\mathrm{Pa}$, which represents the pressure formed by normal outdoor wind field;

Q: Under certain pressure difference, air leakage volume calculated according to Formula (5), $\mathrm{m}^{3} / \mathrm{h}$.

(4) Recommended leakage standards

TM23gives out recommended envelope air tightness technical index, shown in following table:

Table 1 Building external envelope air tightness technical index

\begin{tabular}{|c|c|c|c|}
\hline \multirow{2}{*}{ Building type } & \multicolumn{2}{|c|}{$\begin{array}{c}\mathrm{Q} 50 \\
\mathrm{~m}^{3} /\left(\mathrm{m}^{2} \cdot \mathrm{h}\right)\end{array}$} & $\begin{array}{c}\mathrm{N}_{50} \\
\mathrm{~h}^{-1}\end{array}$ \\
\cline { 2 - 4 } & Qualified & Excellent & - \\
\hline $\begin{array}{c}\text { Residential building } \\
\text { (natural ventilation) }\end{array}$ & 10.0 & 5.0 & - \\
\hline $\begin{array}{c}\text { Residential building } \\
\text { (mechanic ventilation) }\end{array}$ & 5.0 & $<.0$ & 0.6 \\
\hline $\begin{array}{c}\text { Residential building } \\
\text { (passive ) }\end{array}$ & - & 3.5 & - \\
\hline $\begin{array}{c}\text { Office } \\
\text { (natural ventilation) }\end{array}$ & 7.0 & 2.0 & - \\
\hline $\begin{array}{c}\text { Office } \\
\text { (mechanic ventilation) }\end{array}$ & 3.5 & 1.5 & - \\
\hline Large shop & 3.0 & 3.5 & - \\
\hline Industrial building & 10.0 & & \\
\hline
\end{tabular}

(5) Ventilation rate under normal pressure

TM23 gives out conversion ration of ventilation rate under $\mathrm{N}_{50}$ and natural status: 
For residential building, ventilation rate under normal pressure is $\mathrm{N}_{50} / 20$.

For large public building, ventilation rate under normal pressure:

$\mathrm{I}=\frac{1}{60} \frac{Q_{50}}{\mathrm{~S}}$

$\mathrm{S}$ : Area of external envelope wall and roof, $\mathrm{m}^{2}$.

\section{Passive house air tightness test guideline BDT ${ }^{[7]}$}

According to BDT (Guidelines for Blower door Testing of Passive Houses) of PHI, main differences between passive house air tightness test and EN 13829 including following points:

(1) Neither positive pressure test or negative pressure test is enough in EN 13829, but positive pressure and negative pressure test shall be made in BDT;

(2) Low pressure and high pressure test in EN 13829 recommend taking 5 points for test, and interval of each test point isn't more than $10 \mathrm{~Pa}$. BDT recommends taking 10 points for test, and interval of each test point isn't more than $5 \mathrm{~Pa}$.

(3) For large building (volume more than $4,000 \mathrm{~m}^{3}$ ), the guideline points out it is easier for realizing ventilation rate below 0.6 times under $50 \mathrm{~Pa}$ than small building. In order to ensure air tightness of large building, BDT guideline recommends controlling $\mathrm{Q}_{50}$ isn't more than $0.6 \mathrm{~m}^{3} /\left(\mathrm{m}^{2} \cdot \mathrm{h}\right)$ at the same time.

\section{Domestic standards ${ }^{[8]}$}

In China, building overall air tightness test is non-mandatory requirement. Test methods of building overall air tightness are according to "Standard on Testing Energy Efficiency of Public Buildings” JGJ/T 177-2009, and are made according to following steps:

(1) Seal and install adjustable-speed air blower into outer door frame of room;

(2) Use infrared thermography to take photo, and determine leakage point;

(3) Seal non-envelope leakage quantity such as floor drain and air port;

(4) Turn on air blower, and building indoor and outdoor to form stable pressure difference;

(5) Measure indoor and outdoor pressure difference of building. When pressure difference is stable at $\pm 50 \mathrm{~Pa}$, measure and record air flow, and record indoor and outdoor air temperature and outdoor atmospheric pressure.

(6) Ventilation rate under normal pressure:

$$
\mathrm{N}=\left(\mathrm{N}_{50+}+\mathrm{N}_{50-}\right) / 34
$$

\section{Analysis on foreign and domestic standards}

\section{Similarities}

(1) Use blast gate method to test;

(2) Pressure difference uses $\pm 50 \mathrm{~Pa}$;

(3) Recommend uses infrared thermal imaging method to determine leakage point.

Differences

(1) Different test target

Air tightness test in foreign countries starts from residential building, then spreads to non-residential building gradually; at present, only public building energy efficiency test standard is pointed out in China, and no requirements are made on residential building.

(2) Different test conditions

Foreign standards have clear requirements on wind speed, outdoor temperature and indoor and outdoor pressure difference before test; domestic standards haven't clear descriptions on such aspects.

(3) Different test methods

Most of foreign test methods are multi-point test, and curvefitting formula is made on test results to determine air leakage under pressure difference; domestic test method is single point test, and only tests air leakage under $\pm 50 \mathrm{~Pa}$.

(4) Different evaluation index

In foreign standards, except passive house, test results are expressed by air leakage of unit area envelope in unit time, and have clear limit value; in domestic standards, test results are expressed by 
ventilation rate only when indoor and outdoor pressure difference is $50 \mathrm{~Pa}$, and haven't clear limit value.

(5) Different test result processing

Under normal pressure, conversion relation of ventilation rate is different. Foreign standards make analysis based on large quantity of engineering test data, and give out conversion relation of residential building and non-residential building respectively; domestic standards only point out ventilation rate is $\mathrm{N}_{50} / 17$ under normal pressure of public building, but don't make further analysis on $1 / 17$ data source.

\section{Conclusion}

Although building envelope overall air tightness standards in our country have perfect system, by comparing to standards in developed countries and areas such as England and European Union, Chinese standard aren't perfect. While envelope thermal performance index in China is close to that in Europe standards gradually, test and acceptance aspect shall be in line with international norms gradually. Following research works are recommended:

(1) Test external envelope overall air tightness of current residential building in severe cold and cold areas, and understand actual situation of air tightness of current domestic building.

(2) Test air tightness of residential building in provinces and municipalities that implement $75 \%$ energy efficiency standards, and understand overall air tightness situation of building under higher standards.

(3) By combining test situation, recommend when preparing national standards on residential building 75\% energy efficiency, propose the requirements on air tightness index, and prepare relevant test standards.

\section{References}

[1] Rob Coxon. Research into the Effect of Improving Air Tightness in a Typical UK Dwelling [J]. The REHVA European Air-conditioning Journal-Special Issue on Air Tightness, 2013, 50 (1): 24-27.

[2] Wei Pan. Relationships between Air-tightness and Its Influencing Factors of Post-2006 New-build Dwellings in the UK [J]. 2010, 45, 2387-2399.

[3] FengXiaohang, Yan Da, Peng Chen, etc. Analysis on Influence of Building Air Tightness on Energy Consumption of Houses [J]. Heating, Ventilation and Air Conditioning, 2014, 44 (2): 5-14.

[4] JiYongming, Duanmu Lin. Actual Measurement of Air Tightness of New Residential Buildings omDianlian Area [J]. Heating, Ventilation and Air Conditioning, 2014, 45(1): 5-14.

[5] EN 13829. "Thermal Performance of Buildings.Determination of Air Permeability of Buildings.Fan Pressurization Method” [S].

[6] CIBSE. “Technical Memoranda TM23: 2000 Testing Buildings for Air Leakage” [S].

[7] PHI. Guidelines for Blower Door Testing of Passive Houses.

[8] JGJ/T 177-2009. “Standard on Testing Energy Efficiency of Public Buildings” [S]. 